\title{
Introducing Hell in Islamic Studies
}

\author{
Christian Lange
}

In regard to the afterlife, scholars of Islam in the West have demonstrated a remarkably irenic temper, preferring to give far more attention to paradise than to hell. The Islamic hell, for the most part, has been viewed as no more than the mirror image of paradise, an ugly reflection of the beauties and the joys in heaven. Consequently, it has been considered a phenomenon of secondary logical and ontological order, as well as interest. The few general overviews of Islamic eschatology largely bypass the infernal regions, ${ }^{1}$ and the dedicated studies of the Islamic paradise, of which there are a fair number, ${ }^{2}$ cannot be said to be paralleled by the same number of scholarly forays into the Islamic hell. ${ }^{3}$ While the entry on paradise in the second edition of the Encyclopaedia of Islam (1954-2005) counts eleven columns in the printed edition, its entry

1 The most widely cited studies of this kind are Smith/Haddad, Islamic understanding, and El-Saleh, La vie future, each of whom pays much less attention to hell than to paradise. Also shorter overviews tend in this direction. See, for example, the classic study by Meier, The ultimate origin; or the stimulating essay by Reinhart, The here and the hereafter.

2 Al-Azmeh, Rhetoric for the senses; Lange, Paradise in the Islamic religious imagination; Lohlker/Nowak, Das islamische Paradies; MacDonald, Islamic eschatology—vi; Raven, A Kitāb al-Azama; Rosenthal, Reflections on love; Schimmel, The celestial garden. See also the numerous studies of aspects of paradise in the Quran, for example Horovitz, Das koranische Paradies; Jenkinson, Rivers of paradise; Lange, The discovery of paradise; Neuwirth, Reclaiming paradise lost; O'Shaughnessy, Eschatological themes, 76-107; Tubach, Schönheiten; Wendell, The denizens of paradise.

3 Exceptions include Lange, Islamische Höllenvorstellungen; idem, Justice, punishment, 101-75; idem, Where on earth is hell?; Thomassen, Islamic hell. Some studies deal with aspects of hell in the Quran. See Jeschke, Ğahannam und al-nār; Radscheit, Höllenbaum; O'Shaughnessy, The seven names. The only book-length study is the $\mathrm{PhD}$ dissertation of Jonas Meyer, Die Hölle im Islam (Basel 1901). Meyer's study, however, is largely a paraphrase of certain hell sections in a medieval eschatological manual, the al-Takhwîf min al-nār of Ibn Rajab al-Hanbalī (d. 795/1393), and as such offers little analysis. See also Hamza, To Hell and back, which deals specifically with the emergence, in the early centuries, of the theological doctrine of the temporary punishment in hell of Muslim sinners. 
on hell is awarded less than one column. ${ }^{4}$ The more recent Encyclopaedia of the Qur'ān (2001-6) shows a more balanced approach, but still favors paradise (sixteen columns) over hell (twelve columns). ${ }^{5}$ Scholarly symposia and museum exhibits in the area of Islamic eschatology likewise gravitate toward the upper regions of the otherworld. ${ }^{6}$

\section{$1 \quad$ Why (Not) Hell?}

There are two reasons, in my view, for this neglect of hell in Western Islamic Studies. ${ }^{7}$ The first is quite simply that hell is not a particularly comfortable space to inhabit, whether for sinners or scholars. The stigma of bad religion adheres to it, as if it were a subject not worthy of the academy's quest for truth and beauty. ${ }^{8}$ In fact, unless the subject is sublimated into philosophical, ethical and psychological discourse, any kind of eschatology is regularly met with suspicion by scholars of Islam. "The whole basic view of ultimate origins and the hereafter," wrote Fritz Meier, "is hidden in Islamic literature behind a decorative structure of baroque traditions." ${ }^{\prime 9}$ One recognizes in such statements a preference for "profound" rather than "decorative" structures, for taxonomy and categorization, for theological rationalization of the "ultimate." When the literature is found to be internally diverse, or even contradictory (as is the case

4 Gardet, Djanna; idem, Djahannam. Both entries were published in 1965. The entry on "al-Nār" (1995) deals exclusively with fire as one of the four elements.

5 Kinberg, Paradise; Gwynn, Hell and hellfire.

6 The symposia and exhibits that have come to my attention are "The Here and the Hereafter: Images of Paradise in Islamic Art" (Hood Museum of Art, Dartmouth College, 26 March19 May 1991); "Roads to Paradise: Eschatology and Concepts of the Hereafter in Islam" (Göttingen University, 27-31 May 2009); "Gardens of Eternity: Visualizing Paradise in Islamic Art" (Los Angeles County Museum of Art, forthcoming). As regards art exhibits, the focus on paradise should not come as a surprise, as it seems that we are currently a long way away from an appreciation of the esthetics of the Islamic hell. A 2002 colloquium held in Keszthely, Hungary, was optimistically titled "Paradise and Hell in Islam," but of the 17 contributions to the published proceedings (see Dévényi/Fodor [eds], Proceedings), only one is devoted to hell proper (Tottoli, What will be the fate), while another five touch on both otherworldly realms in equal measure, including notably Jones, Heaven and Hell in the Qurān; and Szombathy, Come Hell or high water.

7 Here I repeat, in summary form, an argument that I have proffered elsewhere. See Lange, Justice, punishment $115^{-7}$; idem, Where on earth is hell?

8 For similar comments regarding the lack of interest in popular eschatology in the study of ancient Christianity, see Himmelfarb, Tours of Hell 4.

9 Meier, The ultimate origin 103. 
with much of the eschatological literature in Islam), it is dismissed as "baroque" or even, to quote Meier again, "bizarre."10 Hell only seems to compound the problem. Lacking the esthetic appeal of paradise, as well as the lofty promise of spiritual ascent, hell is a supremely messy and ugly place. Islamic literary traditions about hell, its inhabitants and their punishments are convoluted, often shockingly violent, and frequently obscene.

There are good reasons for scholars, however, to pay serious attention to religious discourses of pain and violence. Robert Orsi has underscored "the importance of studying and thinking about despised religious idioms, practices that make us uncomfortable, unhappy, frightened - and not just to study them but to bring ourselves into close proximity to them, and not to resolve the discomfort they occasion by imposing a normative grid."11 Such an approach may in fact reveal that representations that, at first sight, one may find distasteful or even repugnant follow a certain logic of representing human suffering, and projecting it on others. To quote Orsi again, "to work toward some understanding(s) of troubling religious phenomena is not to endorse or sanction them ... but we cannot dismiss them as inhuman, so alien to us that they cannot be understood or approached, only contained or obliterated."12 The discourse on hell in Islam is no exception in this regard. As is amply demonstrated by the contributions to this volume, hell occupies an important place in the Muslim religious imagination. As such, the function and the meaning of hell in a variety of Muslim discourses deserve to be studied, not in order to sanction phantasies of violence and pain but to understand the conditions and consequences of their flourishing.

The second reason why hell has been largely absent from the map of Islamic Studies is the common perception among scholars that Islam is a religion of mercy; put differently, that it is a religion in which salvation is easily obtained, a religion in which hell, therefore, has no place. According to Gustav von Grunebaum's classic formulation, Islam does away with the idea of original sin and reduces salvation to obedience to an all-powerful God, thus making salvation "a door that is easily unlocked."13 Earlier, Ignaz Goldziher wrote about the "pure optimism" of Muslim soteriology, ${ }^{14}$ a view that one finds repeated

\footnotetext{
$10 \quad$ Ibid., 104. Also Carra de Vaux, Fragments 5, speaks of the "merveilles bizarres" of Islamic eschatology.

11 Orsi, Jesus Held Him So Close 7.

12 Ibid.

13 Von Grunebaum, Ausbreitungs- und Anpassungsfähigkeit 15: “... wird Gehorsam das Tor zur Erlösung, ein Tor, nicht schwierig zu erschließen."

14 Goldziher, Richtungen 160.
} 
in the recent scholarly literature. ${ }^{15}$ Such perceptions, of course, are not without basis. The absence of original sin, and the minimal requirements for faith stipulated in mainstream Islamic theology, have often been noted by scholars. It bears pointing out, however, that characterizations of Islam as a religion of mercy and ready access to paradise have the unfortunate corollary of reinforcing a stereotypical dichotomy between "difficult" and "easy" religions. In this dichotomy, Christianity is presented as a difficult religion, the line from Matthew 7:14, "for the gate is narrow and the way is hard that leads to life, and those who find it are few," being used in support of this claim. Conversely, Islam is characterized as a religion that encourages an attitude of self-indulgence. Islam, wrote Riccoldo of Monte Croce (d. $1320 \mathrm{CE}$ ), one of the most influential European late-medieval polemicists against Islam, is the "easy and wide road" (lata et spatiosa via), quoting Matthew 7:13, "the gate is wide and the way is easy that leads to destruction, and those who enter by it are many."16

The precise degree to which the certainty of salvation characterizes the Islamic tradition remains a subject of debate, despite all generalizations to the contrary. As scholars of Islam gradually discover hell to be a topic worthy of their attention, a more nuanced picture will begin to emerge. This volume is conceived as a contribution to this process of putting hell on the map of Islamic Studies and of locating it in a variety of Islamic traditions. In the remainder of this introduction, I aim to provide a brief reassessment of the assumption of absolute salvific certainty in Islam, followed by a general overview of the hell imagery in Islamic traditions. ${ }^{17}$ Though covering a broad spectrum of intellectual and literary history in Islam (Sunni and Shi i, Quranic, traditionist, mystical, philosophical, modernist, etc.), the contributions in this volume cannot address all aspects of the Islamic hell that deserve study, and they do on occasion presuppose familiarity with some basic givens of the tradition. This introduction, therefore, aims to sketch out this background. In the pages that follow, I shall also highlight certain areas in the infernology of Islam that I consider worthy of further investigation. Along the way, I shall weave in references to the contributions in this volume, even though I will refrain from offering a précis of each of them.

\footnotetext{
15 Van Ess, Flowering 42; Smith/Haddad, Islamic understanding 81.

16 On Riccoldo and medieval European polemics leveled at Islamic soteriology, see Daniel, Islam and the West $177-80$.

17 This overview is an updated and, in places, an expanded version of Lange, Hell.
} 


\section{Hell and Salvation Anxiety}

The Quran stresses both God's heavenly reward and punishment in hell. As Navid Kermani remarks, "in the Quran God is represented in many facets of mercy; however, as in the Bible, these facets are inextricably linked with His violence, His malice and His terror."18 Opinions are divided among scholars as to how much space exactly hell claims in the Quran in comparison to paradise. One scholar counts 92 "significant passages" about hell and 62 about paradise; 19 another identifies about 400 verses relating, in a meaningful way, to hell and about 320 relating to paradise. ${ }^{20}$ Others, however, claim that paradise occupies "significantly more space" in the Quran than hell. ${ }^{21}$

Be that as it may, the imagery of hell is relatively well developed in the Quran.22 It is noteworthy, as Tommaso Tesei shows in his contribution to this volume, that hell in the Quran, like paradise, is conceived to lie immediately ahead; it is now, or almost there already. This explains the apparent lack of interest that the Quran shows in the state of souls between death and resurrection. In the Quran there is the notion that souls fall asleep at death, an idea that Tesei traces to a multitude of late-antique, Christian precedents. Indeed, the picture of hell in the Quran is the result of a confluence of several traditions of eschatological thought of Late Antiquity. There is also, as some scholars contend, a gradual development toward a more Bibilicized version of hell in the Quran. Thomas O'Shaughnessy, for example, has suggested that in the middle Meccan period, the Quran largely abandons the term jahim to designate hell, from now on using more frequently the more Biblical term jahannam (the "valley of Hinnom", Hebr. gē-hinnōm, see Joshua 15:8, Jeremiah 7:31, 32:35). ${ }^{23}$ Christian Lange, in his contribution to this volume, traces a similar pattern, testing the Nöldekian hypothesis of a gradual development of the Quranic hell

\footnotetext{
18 Kermani, Schrecken Gottes 161; cf. See Neuwirth, Form and Structure ii 258a-b.

19 Jones, Paradise and hell 110.

20 Lange, Paradise and hell, ch. 1 (forthcoming).

21 Neuwirth, Koran 439. Tellingly, the index in Neuwirth's study has an entry for "paradise," but not for "hell." Similar statements can be found in Neuwirth, Reclaiming paradise lost 333; Madigan, Themes and topics 91; Sviri, Between fear and hope 323; Andrae, Ursprung 234. Michael Sells contends that it is a "standard stereotype about ... the Qurān ... that Islam is a religion of fear." See Sells, Approaching the Qur'ān, 23. Rosenthal, "Sweeter than hope," 79, leaves the question open.

22 See Gwynne, Hell and hellfire; Lange, Paradise and hell, ch. 1 (forthcoming). See Murata/ Chittick, The vision of Islam 211: "No scripture devotes as much attention as the Koran to describing the torments of hell and the delights of paradise."

O'Shaughnessy, The seven names $45^{-1} 5$.
} 
discourse in four phases, based on an analysis of the terms and ideas used in connection to the punisher-angels in hell. Also Simon O'Meara's chapter in this volume can be read this way, describing as it does a gradual infernalization of the pre-Islamic jinn in the Quran, a process which results in a reconfigured (and appropriately monotheistic) hierarchy of spiritual beings.

In the centuries that followed its proclamation, the Quranic image of hell was greatly elaborated in scores of short narratives traced back to the Prophet or his Companions. These hadiths, from the third/ninth century onwards, were compiled into special eschatological handbooks, from the works of Saiid b. Janāḥ (Shici, fl. early 3rd/gth c.) and Ibn Abī l-Dunyā (Sunni, d. 281/894) to those of al-Ghazālī (Sunni, d. 505/1111), al-Qurțubī (Sunni, d. 671/1272), al-Suyūṭī (Sunni, d. 911/1505), al-Bahrānī (Shíi, d. 1107/1695-6), al-Saffārīn̄ (Sunni, d. 1189/1774), Șiddīq Ḥasan Khān (Sunni, d. 1307/1890) and Muḥammad b. Yūsuf Ațfayyish (Ibādīi, d. 1332/1917), among others. ${ }^{24}$ Some of these compilations are devoted exclusively to hell; ${ }^{25}$ most, however, combine traditions about hell with descriptions of paradise. Mention should also be made of a number of anonymous, popular compilations, in particular the Daqäiq al-akhbārfì dhikr al-janna wa-l-nār ${ }^{26}$ and the text known as Qurrat al-'uyūn. ${ }^{27}$ It is typical of these popular manuals that they were later posthumously connected to (usually) famous authors. Thus, the Daqāiiq al-akhbār is variously attributed to Abū l-Layth al-Samarqandī (d. 373/983), Fakhr al-Dīn al-Rāzī (d. 6o6/1210), or a certain, otherwise unknown 'Abd al-Rahịm al-Qāḍì ( $f$ l. before 11th/17th c.); the Qurrat al-'uyūn is often (and equally mistakenly) said to be the work of al-Samarqandī. Noteworthy about the Daquàiq al-akhbār and the Qurrat al-'uyūn is that they both have a lot more to say about hell than about paradise. For example, ten chapters in the Daqä̇iq al-akhbār deal with the former, only five with the latter. The series of articles of John MacDonald on Islamic eschatology, ${ }^{28}$ a translation of the Daqāiq al-akhbār with some added commentary, completely misses out on this important aspect. This is because MacDonald used a manuscript that happened to lack the hell section

\footnotetext{
24 Cf. the bibliography.

25 See, for example, Ibn Abī l-Dunyā, Șifat al-nār; Ibn Rajab, Takhwīf; Șiddīq Ḥasan Khān, Yaqzat. On the development of the genre of traditionist eschatology, cf. Bauer, Islamische Totenbücher; Lange, Paradise and hell ch. 2 (forthcoming).

26 See on this text, Tottoli, Muslim eschatological literature; Lange, Paradise and hell, ch. 3 (forthcoming).

27 Another specimen is the text known as al-Durar al-hisān, commonly (and probably mistakenly) attributed to al-Suyūtị. There is also debate about the correctness of the ascription of al-Durra al-fākhira to al-Ghazālī.

28 MacDonald, Islamic eschatology I-VI (1964-66).
} 
of the text. ${ }^{29}$ As for the Qurrat al- uyūn, all ten of its chapters offer discussions of mortal sins and their punishments in hell. Only in the last chapter does one find a vision of paradise, which connects awkwardly to the rest of the text and may be a later addition.

For those reading or listening to the Quran and the hadiths on the afterlife, therefore, fear of hell was rather difficult to avoid. Of course, many Quranic verses and certain hadiths strike a more optimistic tone. One should also note that theologians of the formative and classical period developed an arsenal of concepts that were apt to mitigate the anxiety the believers may have felt. This included a broad, belief-based definition of faith (immann), the affirmation of the possibility of repentance (tawba) for sins, and the doctrine of the intercession (shafä $a$ ) of the Prophet. Nonetheless, salvation anxiety was hardly absent in Islamic theology, as one realizes when studying Muslim doctrines of sin and salvation. Here, much depends on the definition of the major sins, the kabäir, which are opposed to the șaghäir, or minor sins (cf. Q 18:49). As in the Christian tradition, these major sins were held to constitute a ticket to hell, whereas the șaghäir, according to the majority position, would be of no consequence. However, how many major sins should one reckon with? Traditions counting three, four, or seven major $\operatorname{sins}^{30}$ could not prevent the emergence of longer lists, a process that culminated in the discussion by al-Dhahabì (d. 748/1348) of seventy-five, and by Ibn Hajar al-Haythamī (d. 974/1567) of 467 major sins. The often-quoted definition attributed to the Companion, Ibn 'Abbās (d. 68/ 686-8), that a major sin is "everything for which God has prescribed a fixed punishment (hadd) in this world and the Fire in the hereafter"31 was hardly apt to restrict the scope of the major sins. One should note that there was a near consensus among Muslim theologians of the later periods that punishment for Muslim grave sinners would only be temporary; eventually, after a purgatory sojourn in hell's top layer, they would be admitted into paradise. ${ }^{32}$ But hell was where they were destined. Over the course of the centuries, the discussion came to center not on whether there would be punishment of Muslims, but on how long and how violent this punishment would be.

There was also the question whether God could forgive unrepented grave sins, and whether in practice He would do so. Theologians, particularly those

29 Similarly, Rustomji, The Garden and the Fire, 108-10.

30 Bukhārī, Șaḥịh, k. al-adab 6, k. al-shahādāt, bāa 10; Muslim, Șaḥịh, k. al-īmān 144. Hadiths in al-Bukhārī's and Muslim's collection are cited according to Wensinck, Concordance.

31 Dhahabī, Kabā'ir 6.

32 On the emergence of the idea of a temporary hell in early Islam, see Hamza, To Hell and back. 
belonging to the Ash'arite school of theology, tended to assert that God's mercy, as one could read in a hadith, would overcome the wrath He directs at human sinfulness, even in the absence of repentance. In contrast, Khārijite

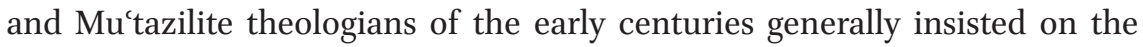
punishment of sinful, unrepentant believers. As noted above, the dominant narrative in scholarship on Islamic theology has been that the Khārijite and Mu'tazilite position was lastingly defeated and erased by the salvific optimism of the mainstream. However, also in later centuries theologians reached different conclusions as to whether God could "renege on the threat" (khulfal-waid) that is leveled at Muslim sinners in the Islamic revelation. ${ }^{33}$ For example, the Meccan Māturīdī scholar, al-Qārī al-Harawī (d. 1014/1605), who dedicated an epistle to the question of khulf al-wai id, affirmed the general necessity for God to punish Muslim sinners, although he also granted that God did not have to punish them in each case (thereby parting ways with the more rigorous stance of many Mu'tazilites). ${ }^{34}$ At the other end of the theological spectrum one comes across notions of universal salvation even for non-Muslims. Mohammad Hassan Khalil and Jon Hoover, both of whom are contributors to this volume, are to be credited for recently having brought these strands of universalist thinking to the attention of a broader audience. ${ }^{35}$ In his chapter, Khalil revisits the eighth/fourteenth-century debate about Ibn Taymiyya's (d. 728/1328) doctrine of the "demise of hell" ( fanäal-nār). Hoover pursues the doctrine's reception in later centuries, particularly in the work of the Yemenite Ibn al-Wazīr (d. 840/1436).

The fear of hell is also integral to the renunciant and ascetic strands of Muslim religiosity. According to a tradition reported by Abū Țālib al-Makkī (d. 386/998), after a thousand years of punishment, only those Muslim sinners who are "more highly esteemed in the eyes of God" are let out of hell. The pious exemplar of the early second/eighth century, al-Ḥasan al-Bașrī (d. 110/728), supposedly commented: "O, that I might be among these men!"36 Other renunciants (zuhhād, sg. zāhid) of the early centuries are on record for expressing what Christopher Melchert has characterized as "exaggerated fear." ${ }^{37}$ In his contribution to this volume, Melchert collects traditions that showcase instances in which the renunciants focused their fear on hell in particular.

See on the rejection of khulf al-wa ìd, particularly among Māturīdì theologians, the comments of Gardet, Dieu 304; Lange, Sins, expiation 160-67.

34 Qārī, Qawl 46-7.

35 Hoover, Islamic universalism; Khalil, Islam. See also Pagani, Vane speranze.

36 Makkī, Qūt al-qulūb (tr. Gramlich) iii, 221.

37 Melchert, Exaggerated fear. 
As one learns from Melchert's piece, several of the zuhhäd allegedly wept, fainted, or even died on the spot when passing blacksmiths working a forge, overwhelmed by the thought of hell-fire. ${ }^{38}$ Such behavior resonated closely with a Quranic motif. "Have you not considered the fire that you light?" the Quran rhetorically asks, and then exclaims: "We have made it a reminder (tadhkira)!" (Q 56:71-3). There are also cases reported of zuhhäd who passed away upon hearing the Quran's hell verses (āyāt al-wa'id) recited to them. ${ }^{39}$

Zuhd motifs of the fear of hell also survive in later Sufi works. "Your coming unto it [hell] is certain, while your salvation therefrom is no more than conjecture", thunders al-Ghazâlī (d. 505/1111) in his Ihyyā' ulüm al-dìn, urging the believer to "fill up your heart, therefore, with the dread of that destination."40 Others voiced a certain disregard for hell. Like paradise, they considered hell a distraction from the only valid object of their devotion, that is, God. This explains how a Sufi like Bāyazīd Basțāmī (d 234/848 or 261/875) could assert that God's fire of love burns a thousand times more intensely than the fire of hell, and that God will take the foot of the hell-monster and dip it into the fire of His love, which will obliterate it. ${ }^{41}$ Bastāamī is also said to have claimed that he would be able to smother hell with the tip of his frock, thereby saving the rest of humankind from punishment. ${ }^{42}$ The idea of universal redemption from punishment in hell also appears in the thought of a later Sufi, Ibn al-Arabì of Murcia (d. 638/1240). As Samuela Pagani's contribution to this volume shows, on the one hand Ibn al-'Arabī makes room for hell as the manifestation of God's attribute of "majesty" (jalāl), which complements His "kindness" (jamāl). On the other hand, Ibn al-'Arabī predicts that punishment in hell will eventually come to an end. However, instead of moving on to paradise, hell's inhabitants will remain in hell, attached to it, and in a certain way enjoying it, like natives prospering in their homeland (mawțin), albeit in a state considered abject by all others.

Yet other Sufis developed strategies of internalizing hell. The Persian mystic Hujwīrī (d. 465/1073 or 469/1077), for example, wrote that man's lower soul (nafs), the seat of carnal appetites, corresponds to hell, "of which it is a type in

\footnotetext{
38 Ibn Abī Shayba, Mușannaf xiv, 5, 8; Ibn Hanbal, Zuhd 320.

39 See the biographies collected in al-Tha'labī's Qatlā l-Qur'ān. Cf. Kermani, Gott ist schön 378-9; Meier, Abū Saìd 196-7. Famous among the "verses of threat" (āyāt al-waìd) were 4:37, 23:104, 39:46, 54:46, as well as suras 67 and 102.

42 See Ritter, Aussprüche 237.
} 
this world." ${ }^{33}$ The Khurasani 'Azīz-i Nasafì ( $f l$. middle of 7 th/13th c.), a follower and interpreter of Ibn al-'Arabī, describes an ethical hell, in which "all the disapproved words and deeds and all the blameworthy manners are the gates of hell",44 a notion that one also encounters in the writings of al-Ghazāli and Rūmī, among others. ${ }^{45}$ In addition, Nasafì outlines an intellectual, or noetic hell: this comes about when the human faculties of perception and understanding (the outer and inner senses) are, as it were, out of balance. If reason ('aql), one of the inner senses, controls the five outer senses, as well as the two inner senses of imagination (khay $\bar{a} l)$ and phantasy (wahm), together they are the eight gates of paradise; if however reason is absent, the remaining seven faculties equal the seven gates of hell. ${ }^{46}$

It should not surprise us that this kind of interiorization and intellectualization of paradise and hell also goes on in Islamic philosophy. Nașīr al-Dīn Ṭūsìs (d. 672/1274) al-Mabda'wa-l-ma'ād, for example, echoes Nasafìs scheme closely. ${ }^{47}$ Țusī, in the beginning of his career, was an Isma'ili; the Isma'ilis, as is well known, were particularly drawn to Neoplatonic thought. Isma ili authors such as Abū Ya'qūb al-Sijistānī (d. after 361/971) deny the resurrection of bodies; ${ }^{48}$ paradise and hell, for them, is a purely spiritual affair. "Impure" and "dark" souls, in al-Sijistānīs language, those that are not enlightened by the teaching of the Isma'ili Imam, suffer the torments of hell already during their earthly lives. ${ }^{49}$ They may also undergo metempsychosis, that is, rebirth in another body or lower material form, a controversial motif in Isma'ili thought that is explored in Daniel de Smet's contribution to this volume, a study that provides a useful overview of Isma ili speculations about hell and the punishments suffered therein. As de Smet writes, Isma'ili thinkers such as Ḥamīd al-Dīn al-Kirmānī (d. after 411/1020) believed that the literal (zāhir) sense of the descriptions of paradise and hell in the Quran and the hadith was "absurd and contrary to reason", and that one should at all times seek to understand their allegorical (bāțin) meaning.

However, few mystics or philosophers in the Islamic tradition, though often latently critical of the traditional imagery of the afterlife, categorically and outspokenly rejected this imagery. In literary circles, it was on occasion

\footnotetext{
43 Hujwīīi, Kashf (tr. Nicholson) 199.

44 Nasafì, Insān 295.

45 See Ghazālī, Ihyyà v v, 165-6 (tr. Winter 235); Rūmī, Mathnawī vii, 68.

46 Nasafì, Insān 295-6.

47 Ṭūsī, Mabda' 77-8 (§§ 65-6).

48 See, for example, Sijistānī, Kashf 120 (§ 7.2.3), 122-4 (§ 7.3).

49 Sijistānī, Risāla 45, 48-9.
} 
ridiculed, ${ }^{50}$ but such satire was patently fictional, and functioned within contexts characterized by their relative distance to institutionalized religion. Not only was the mass of details in the Quran and hadith about the material and sensual nature of the afterlife rather difficult to ignore. There was a theological consensus that one should accept the "reality" (haqq) of the phenomena in paradise and hell without inquiring into what kind of reality, exactly, these phenomena possessed. ${ }^{51}$

In the popular religious literature of the Middle Period and Late Middle Period hell is prominently on display. ${ }^{52}$ Roberto Tottoli's chapter in this volume provides insights into several of these narratives, albeit in a somewhat unexpected context, that of Spanish Morisco literature. A community under siege in its Christian environment, the Moriscos transmitted several texts about hell. This, as Tottoli shows, is not so much due to a certain Morisco pessimism in the face of their Christian persecutors; it is characteristic, rather, of latemedieval Islamic literature in general. One can also think in this context of the stories about the Prophet Muhammad's Ascension (mi'rāj), in which, over the course of the centuries, hell (but also paradise) is given more and more space. ${ }^{53}$ Frederick Colby, in his chapter in this volume, traces a curious development in this body of texts, whereby hell is gradually moved up toward the higher heavenly spheres. Rather than seeing in this the attempt to remove the otherworldly realms from earth, that is, to make them more transcendental, one should probably interpret this phenomenon as the result of a process of literary elaboration of the narrative: the Prophet's visit to paradise and hell comes at the end of his otherworldly journey because it heightens the dramatic effect and fits more neatly into the chronology of events. In fact, perhaps one should regard the kind of narratives discussed by Tottoli and Colby as skeletal versions that story-tellers performed in public, enriching them with other traditions. It is not difficult to imagine that hell in particular would have offered ample opportunities to do so. In the following two sections of this introduction, I provide an overview of the wide and varied pool of traditions from which storytellers could draw.

$5^{0} \quad$ An extreme example is Wahrānī, Manām.

$5^{1}$ See, for example, Ash'arī, Maqālāt 293, and the credal affirmations of the haqq of eschatological phenomena in Watt (tr.), Islamic creeds 44 (§ 17, al-Ash'arī), $5^{2}$ (§ 8, al-Ṭahāāī), 60 (§§ 20-21, Wāṣiyat Abì Ḥanīfa), 66 (§ 21, Fiqh akbar II ), 71 (§ 12, al-Qayrawānī), 77-8 ( § 17-21, al-Ghazālī), 82 (§ 17, al-Nasafì), 88 (§ 18, al-İjīi). Tottoli, Jesus and the skull.

53 On hell in Ascension narratives, see Vuckovic, Heavenly journeys 113-21; Tottoli, Tours of Hell; and the contribution of Frederick Colby to this volume. 
The common belief was that hell, like paradise, coexists in time with the temporal world. Q 3:131, which states that "hell has been prepared (uiddat) for the unbelievers," was generally taken to mean that, rather than coming into being at the end of time, hell was "already created." ${ }^{4}$ The fact that the prophet Muhammad, during his Ascension, had seen the punishment of Muslim sinners in hell was also taken to be proof for hell's coexistence. ${ }^{55}$ While, as noted above, some theologians held that only paradise was eternal, while hell would eventually perish ( $f a n \bar{a}$ al-nār $)$, the majority agreed that hell too was eternal unto eternity, that is, a parte post (abad) (cf. Q 4:169, 5:119, passim). ${ }^{56}$

Given the temporal coexistence of hell, there was some speculation as to where in the cosmos hell is located. The "seven earths" mentioned in Q 65:12 were interpreted to be the seven levels (țabaqāt) of hell..$^{57}$ The Quranic sijjin ("a written record," Q 83:7-9), was commonly thought to be a rock in the lowest earth ${ }^{58}$ on which the whole universe rests. ${ }^{59}$ If, then, hell was (in) the lower part of the globe, it made sense to picture it as a vast subterranean funnel, spanned by the Bridge (șirāt), which the resurrected pass on their way to paradise, ${ }^{60}$ with a brim (shafir) and concentric circles leading down into a central pit at the bottom $\left(q a^{i} r\right){ }^{61}$ Eschatologists also debated the location of the entry to this subterranean structure. Some related that the sea is the top level of hell. ${ }^{62}$ Others believed that the sulphurous well in the Wādì Barhūt in Hadramawt (modern-day Yemen), haunted by the souls of infidels, was the gate to the nether regions. ${ }^{63}$ Still others located the entry to hell in Gehinnom, the Biblical valley of Hinnom, between the eastern wall of the Jerusalem temple precinct and the Mount of Olives. ${ }^{64}$ Further east, a Persian work of the mirabilia genre from the sixth/twelfth century locates the entry to hell in a gorge, appropriately called Wādī Jahannam, in the neighbourhood of Balkh in

\footnotetext{
54 Ash'arī, Maqūà̄àt 475; Pazdawī, Ușūl al-dīn 170.

55 Qurțubī, Tadhkira ii, 98.

56 Abrahamov, The creation and duration 96.

57 Yāqūt, Buldān i, 20.

58 Ibn Ḥanbal, Musnad iv, 287; Muttaqī, Kanz xv, 265.

59 Heinen, Islamic cosmology 88, 143.

$60 \quad$ Bukhārī, Șaḥịh, k. al-riqāq 52; Muslim, Șaḥịh, k. al-ïmān 299.

61 Qurțubī, Tadhkira ii, 108.

62 Ibid., 101, 105; Suyūṭī, Budūr 411.

63 Fākihī, Akhbār Makka i, 41, 43 (\#\# 1106, 1110); Qurrat al-'uyūn 104; Suyūṭī, Sharh al-ṣudūr $312-3,317-8$, 330. Cf. Rentz, Barhūt; $T G$ iv, $5^{22}$.

64 Wāṣițī, Faḍ̂ảil 23. Cf. Monfarrer, A propósito 152.
} 
Afghanistan. The author says of this sinister venue that it "sinks steeply into the ground, and the fearless and ruthless joke that it goes down so deeply that if one throws a stone into the cavity one cannot see it reaching the bottom." 65 He also notes that "in this cavity, strange birds have countless nests", an observation that accords with the notion that the souls of infidels and sinners haunt the gate to hell in the bellies of black birds. ${ }^{66}$ In this account, one also hears echoes of eschatological hadiths which describe the extreme depth of the hell funnel, where a stone thrown from the Bridge falls for seventy years before hitting the ground. ${ }^{67}$ In sum, there is a general trend in the tradition to think of this world and hell as being temporally and spatially coterminous.

Q 15:44 states that hell has seven gates (abwäb), which were equated with hell's seven levels (țabaqāt), mirroring the seven levels of paradise. At times, a terminological distinction was made between the levels of paradise, called darajāt (stairs upwards), and the levels of hell, called darakāt (stairs downwards; cf. Q 4:144). ${ }^{68}$ The name for hell that is most often used in the Quran (some 125 times) is simply "the Fire" (al-nār). In the exegetical literature, seven of the other names for hell in the Quran were singled out and correlated with the seven levels of hell. According to the most common model, the descending order of these levels is as follows:69 (1) jahannam "Gehenna", a cognate of Hebrew gehinnom (Q 2:206, 3:12, passim in 109 places); (2) al-sa'ir "the blaze" (Q 4:10, 4:55, passim in fourteen places); (3) al-huțama "the crusher" (?) (Q 104:4-5); (4) laza "blazing fire" (Q 70:15); (5) saqar "extreme heat" (?) (Q 54:48, 74:26-7, 74:42); (6) al-jahim "the furnace" (Q 2:119, 5:10, passim in twenty-four places); and (7) hāwiya "pit, abyss" (Q 101:9). Various similar models exist with a slightly differing order of names. Al-Qurțubī warns against other, less sound divisions, ${ }^{70}$ possibly referring to models such as that recorded by al-Thalabī (d. 427/1035), in which the seven layers of hell appear to merge with the seven earths of medieval Islamic cosmology and are called adim (surface), basịt (plain), thaqül (heavy, onerous), bațịh (swamp), mutathāqila (oppressor), mäsika (holder), and tharā (moist earth). ${ }^{71}$ One may also refer to the concept of Ibn al-'Arabī and other Sufis of hell as a meganthropos, in which the seven

\footnotetext{
65 Țūsī, 'Ajāyib 293-4.

66 Țabarī,Jāmi xxiv, 71. Cf. TG iv, 523.

67 Qurțubī, Tadhkira ii, 108.

68 Ibid., 89; Suyūṭī, Budūr i, 69.

69 Cf. O'Shaughnessy, The seven names 444-69.

70 Qurțubī, Tadhkira ii, 90.

71 Tha'labì, Qișaș 6-7.
} 
body parts with which man sins (eyes, ears, tongue, hands, stomach, genitals, and feet) are equated with the seven levels of hell. ${ }^{72}$

As noted above, hell's uppermost level, called jahannam, was seen as a temporary place of punishment reserved for Muslim sinners. In later tradition, one finds the notion that hell has only two levels (bābān), an inner one (al-jawāniyya), from which nobody ever escapes, and an outer one (al-barräniyya), in which Muslims are kept. ${ }^{73}$ However, this place of temporary punishment never crystallised into a "third place" between paradise and hell as in the Christian tradition of purgatory. In common parlance, the term jahannam continued to be used pars pro toto, and it remained a place not outside or above hell, but part of it; it was not to be confounded with al-a'rāf (cf. Q 7:46), a residual place or limbo situated between paradise and hell, in which there is neither reward nor punishment.

Hell is so large that one must travel for five hundred years in order to get from one level to the next. ${ }^{74}$ Hell's pitch-black darkness ${ }^{75}$ is only faintly illumined by the flames of the infernal fire. ${ }^{76}$ Extreme heat predominates, but, according to some traditions, the bottom level of hell is freezing cold (zamharir, cf. Q 76:13). ${ }^{77}$ According to a well-known tradition, the extreme heat in summer and the extreme cold in winter are the two breaths of hell that God grants it as a means to relieve the pressure at work in it, its parts "eating each other."78 Mountains, valleys, rivers, and even oceans (filled with fire, blood, and pus) are thought to form the landscape of hell. The Quranic terms șa'üd (74:17), yahmūm (56:43), and 'aqaba (90:11) were interpreted as names referring to mountains in hell. ${ }^{99}$ Traditions that improvise on multiples of seven are common: hell has seventy thousand valleys, each with seventy thousand ravines, inhabited each by seventy thousand serpents and scorpions. ${ }^{80}$ In hell, there are dry and thorny shrubs, the $\operatorname{dari~}^{\top}(\mathrm{Q}$ 88:6) and ghislin (Q 69:36). According to Q 37:62-6 and 44:43-6, the tree of zaqqūm, commonly identified with the "cursed tree" (al-shajara al-mal'ūna) of Q 17:60, grows at the bottom of hell (fi așl al-jahìm), sprouting fruit "like the heads of demons" (ka-annahu ru'üs al-shayâțīn), which

\footnotetext{
72 Asín, La escatología musulmana 145. See above, n. 42.

73 Muttaqī, Kanz xiv, 216.

74 Qurțubī, Tadhkira ii, 93.

75 Tirmidhī, Jāmi, k. jahannam 8; Muttaqī, Kanz xiv, 220.

76 Abū Nu'aym, Hilya vi, 139.

77 Cf. Asín, La escatología musulmana 152; Tottoli, Case of zamharìr.

78 Bukhārī, Șaḥịh, k. bad' al-khalq 10.

79 Ṭabarī, Jāmi xxiv, 155; Qurțubī, Tadhkira ii, 114, 119.

80 Ghazālī, Ihyyā’ v, 157 (tr. Winter 221-2).
} 
the inhabitants are forced to eat as one of their tortures. When the inhabitants of hell eat from it, zaqqüm snaps back at them. ${ }^{81}$ Commentators debated whether zaqqüm is "from this world" (min al-dunya $)$ or whether it is exclusively an otherworldly phenomenon. According to al-Tha'labī, the majority position was that zaqqüm is a desert tree known to the Arabs. ${ }^{82}$ All in all, the learned tradition of Islam embraced the notion of a geomorphic hell, as is also attested by the postulation of cities, palaces, houses, wells, and prisons in hell..$^{83}$

On the one hand, then, hell appears as a rather mundane setting; on the other, the traditionist literature on hell continuously seeks to push the human imagination to its limits. One might say that in this literature the unimaginable is approximated asymptotically. Infinite space, for example, is gauged in terms of distance measured in very large units of travel time. The popular eschatological literature pushes this idea to its extreme, resulting in traditions in which the imagination is "unbound." 84 In this volume, Wim Raven provides an impression of just such a popular narrative, an anonymous fantastic cosmology known under the title of K. al-Azama ("The Book of Majesty"), which has been ascribed, wrongly it seems, to Ibn Abī l-Dunyā. It is striking how in the K. al-Azama the hundreds and thousands of years one encounters in the learned traditionist literature on hell are exponentially increased to multiples of thousands and millions. For example, each tooth of the hell-monster, one learns, "has a length of a billion years, a year being four thousand months; a month being four thousand days; a day being four thousand hours, and one hour lasts as long as seventy of our years."

The hell-monster Jahannam, which "raises its neck out of the Fire on the Day of Resurrection," 85 is just the most prominent among the array of animal punishers in hell. Snakes and scorpions figure prominently, ${ }^{86}$ but the damned also have to do with vermin and "all flying insects, to the exception of bees," ${ }^{\prime 8}$ as in fact all animals that inflict pain on earth, according to one tradition, continue

\footnotetext{
81 Abū Nu'aym, Hilya vi, 11.

82 Tha'labī, Tafsìr viii, 146.

83 Qurțubī, Tadhkira ii, 94.

84 Cf. Abu-Deeb, The imagination unbound.

85 Ibn Hanbal, Musnad ii, 336; Muttaqī, Kanz iv, 17.

86 Tha'labī, Qișaș 6; Qurțubī, Tadhkira ii, 114 and passim.

87 Suyūṭī, Budūr 444. Cf. Canova, Animals 65.
} 
to do so in the next.88 (By a process of punitive transformation [maskh], the sinners also turn into animals themselves, a punishment that serves to dehumanise them. $)^{89}$ The staff of hell, however, is formed first and foremost by an army of fearsome punisher-angels. In a strictly monotheistic system like Islam, there is no place for Satan as the lord of hell; a relatively peripheral figure in Islamic eschatology, he is simply counted among the inmates of hell. According to Q 74:30, there are nineteen guardian angels of hell, who guard the gates of hell ( $Q$ 39:71) and are charged with punishing its detainees under the supervision of their chief, called Mālik (Q 43:77). In the exegetical literature and in popular eschatology, these guardian angels (khazana) are identified with the "repellers" (zabāniya) mentioned in Q 96:18, and their number is expanded ad infinitum. ${ }^{90}$ The zabāniya have repulsive faces, eyes like flashing lightning, teeth white like cows' horns, lips hanging down to their feet, and rotten-smelling breath, and they dress in black clothes. ${ }^{91}$ Evil demons, the followers of Satan, are punished in hell, along with humans (Q 26:95). The punisher-angels in hell, on the other hand, are on God's side, as agents of His terrifying but ultimately just use of punishment.

Almost every punishment found in the catalogue of medieval Islamic punishments is also found in the imagined realm of hell. Fire is by no means the only source of suffering. ${ }^{92}$ There are executions by decapitation, gibbeting, stoning, throwing down from heights, drowning, and trampling by animals. ${ }^{93}$ Corporal punishments, in addition to flogging, ${ }^{94}$ appear in all forms, of which a ninth/fifteenth-century Uighur mir $\bar{x} \bar{j}$ manuscript offers vivid depictions. ${ }^{95}$ Sinners are tied up in torturous positions, left hand chained to neck. ${ }^{96}$ They are hung up with ropes, dangling from their feet, calves, Achilles tendons, breasts, hair, and tongues. ${ }^{97}$ Lips are cut with scissors, corners of the mouth slit all the way back to the neck. ${ }^{98}$ Another important punishment incurred by the sinners is shaming. Already in the Quran it is stressed that the inhabitants

\footnotetext{
88 Suyūțī, Budūr 445.

89 Qurrat al-'uyūn 70; Tha'labī, Tafsìr iv, 57.

9o Samarqandī, Tafsìr iii, 494. On the translation of zabāniya as "repellers," see Christian Lange's contribution to this volume.

91 Ghazālì, Durra 17.

$92 \quad$ Pace El-Saleh, Vie future 51.

93 Lange, Justice 147-8.

94 Abū Nu'aym, Hilya vi, 10-1; Daqā̇iq al-akhbār 66.

95 See Séguy, The miraculous journey, plates 46-57.

96 Daqāंiq al-akhbār 66.

97 Qushayrī, Mírāj 47.

98 Bukhārī, Șạīh, k. al-tábīr 48.
} 
of hell will suffer exposure and humiliation (6:124, 25:69, 40:60). The most obvious illustration of this is the fact that sinners in hell are naked, ${ }^{99}$ but the face, as the seat of honour, is singled out for punishment. ${ }^{100}$ Faces are beaten (Q 8:50, 47:27) and "blackened" by the heat (Q 23:104; cf. 3:106). Sinners "will be dragged on their faces into the Fire" (Q 54:48). The hadith elaborates with grotesque detail: The zabanniya trample the sinners' tongues. ${ }^{101}$ Hellfire is so fierce that the upper lip of the sinner "is rolled up until it reaches the middle of his head, and his lower lip will hang down until it beats on his navel."102 On the basis of Q 3:180 ("That which they held on to will be tied to their necks on the Day of Resurrection"), hadith traditions conjecture that sinners will be carrying visible signs of their sins into hell with them. ${ }^{103}$ Spurred by the fact that the Quran speaks of the many chains with which the sinners will be bound (40:71-2; 73:12), many exegetes conceived of hell as a place of imprisonment. Al-Ghazālī imagined hell as a house with narrow walls and dark passageways in which the prisoner (asir) dwells forever. ${ }^{104}$ Some exegetes were of the opinion that sijjin was the name of a prison in hell. ${ }^{105}$ Finally, hell could also be seen as a place of banishment (that is, from paradise), "the worst punishment of the people of hell."106

Assigning certain sinners to hell reinforced a parallel moral hierarchy in the lower world. It is therefore not surprising to see the basic social classes and other divisions of medieval Muslim society reflected in the social stratification of hell, which is populated by common people, members of the learned religious elite, and rulers and their representatives. Traditions enumerating the punishments that await them in hell may well have served the lower classes as a kind of moral catechism. Along with their general condemnation of those who engage in wine-drinking, fornication, sodomy, suicide, and so forth, eschatologists also include among the damned those "who speak of worldly matters in the mosque" or sleep during prayer. ${ }^{107} \mathrm{~A}$ tradition allocates seven types of mischievous scholars ('ulam $\bar{a}^{\prime}$ ) to the seven different levels of hell. ${ }^{108}$ Corrupt

\footnotetext{
99 Qushayrī, Mírāj 37; Daqā’iq al-akhbār 69.

100 See Lange, "On that day."

101 Qurțubī, Tadhkira ii, 124.

102 Ibn Ḥanbal, Musnad iii, 88; Tirmidhī, Jāmi, k. jahannam 5.

103 'Abd al-Razzāq, Mușannaf, k. al-zakāt, bāb ghulūl al-șadaqa iv, 55; Bukhārī, Șahịh, k. al-jihād 189; Muttaqī, Kanz v, 222.

104 Ghazālī, Ihyyā' v, 156 (tr. Winter 220).

105 Rāzī, Tafsìr xxxi, 84.

106 Ibn Rajab, Takhwif 143.

107 Qushayrī, Mírāj 40, 47; Daqā̉iq al-akhbār 70.

108 Muttaqī, Kanz x, 82.
} 
judges and hypocritical Quran readers are likewise assigned to hell. ${ }^{109}$ Other traditions seem, often in oblique ways, to allude to policemen, tax-collectors, and market inspectors, as well as a number of other state officials. ${ }^{110}$ The ruler himself is not exempted from such threats. Al-Ghazālī cites a report from the Prophet that those rulers who punished their subjects beyond what God commands "will be shown the corners of hell."111 Such traditions suggest that the popular discourse on hell could have the double function of promoting an attitude of quietism and at the same time subverting the social status quo.

There is no shortage in the traditionist literature of patriarchal, at times overtly misogynist statements about women. At its most blunt, this is clothed in the tradition attributed to the Prophet that "most people in hell are women."112 Descriptions of the punishment of female sinners in hell do not make for pleasant reading. ${ }^{113}$ As Jane Idleman Smith and Yvonne Haddad have noted, these description, however, should not be seen as "the considered conclusion of Muslim theologians ... but rather [as] the attempt to legitimate forms of social control over women."114 A similar dynamic is at work in hell traditions about non-orthodox Muslim and other minority groups. The apostle Paul (Bawlus), according to a Shici tradition, is in hell;:115 the atheists (dahriyya) and antipredestinarian Qadarites keep him company there. ${ }^{116}$ Christiane Gruber's analysis in this volume of a Safavid hell painting demonstrates how, in her words, "hell played a key role in sectarian politics." In sum, eschatologists identified and classified sinners in hell in accordance with how they understood andby reproducing traditions that underpinned them-perpetuated the genderbased, moral, social, political and sectarian hierarchies of medieval Islam.

\section{$5 \quad$ The Islamic Hell and Modernity}

The various ways in which modern and postmodern Muslim thinkers of the late nineteenth, twentieth and twenty-first centuries have reacted to the

\footnotetext{
109 Ibid., xi, 179 .

110 Abū Nu'aym, Hilya iv, 2, 112; Qurțub̄̄, Tadhkira ii, 76-7, 130; Muttaqī, Kanz iii, 200, vi, 18.

111 Ghazālī, Nașîhat al-mulk 22.

112 Suyūțī, Budūr 46o-61.

113 Cf. Malti-Douglas, Faces of sin.

114 Smith/Haddad, Islamic understanding 163. On this issue, see also the balanced remarks by Rosenthal, Reflections on love $251^{-2}$.

115 Majlisī, Bihāar viii, 483.

116 Qurțubī, Tadhkira ii, 92; Suyūṭī, Budūr 423; Majlisī, Biḥār viii, 353.
} 
modern onslaught on traditional eschatology deserves separate, detailed study. Jane Idleman Smith and Yvonne Haddad are pioneers in this field of inquiry. ${ }^{117}$ In conclusion to this introduction, I shall limit myself to some general observations, while seeking to highlight aspects of modern Muslim theology that relate to hell in particular.

Muslim modernists, in the words of Smith and Haddad, experience a "kind of embarrassment with the elaborate traditional detail concerning life in the grave and in the abodes of recompense, called into question by modern rationalists." 118 According to Smith and Haddad, "the great majority" of modern Muslim theologians, therefore, silence the issue, or content themselves with reaffirming the traditional position that the reality of the afterlife must not be denied, but that its exact nature remains unfathomable. ${ }^{119}$ More radical, skeptical reactions can also be found, however, including ironic reversals of traditionalist eschatology such as one encounters in Jamīl Șidqī al-Zahāwī's (Iraq, d. 1936) remarkable poem, Thawra fijahịm ("Revolution in hell"), which is discussed in Richard van Leeuwen's contribution to this volume. In al-Zahāwìs visionary tale, which is clothed in the form of a dream of his own death that the poet has after eating a dish seasoned with watercress, ${ }^{120}$ hell is where the philosophers and rationalists are, that is to say all the forward-thinking, revolutionary spirits that traditionalist Islam condemns to eternal damnation: Ibn Sīna, Ibn Rushd, and Țūsī, but also Socrates, Epicurus, Voltaire, and Spinoza, to name just a few. Fired up by the passionate address of a young male revolutionary, and with the aid of infernal weaponry developed by a group of empirical scientists, the inhabitants of hell storm heaven and threaten to topple God's Throne-but then the poet wakes up. ${ }^{121}$ Al-Zahāwī's poem unmistakably gestures back to earlier literary tours of the otherworld, in particular al-Ma'arri's (d. 449/1058) Risālat al-ghufrān ('Epistle of Forgiveness'),, ${ }^{122}$ but updates it and frames it in modern terms.

\footnotetext{
117 Smith/Haddad, Islamic understanding 99-146. For a recent overview, critical of Smith/ Haddad, see Ryad, Eschatology (forthcoming).

118 Smith/Haddad, Islamic understanding 100.

119 Ibid.

120 Watercress is the only edible plant that grows in the Muslim hell, viz., in jahannam, hell's uppermost layer where live becomes just about bearable. See Suyūṭi, Budūr 480; Majlisī, Bihāar viii, 479 .

121 Zahāwī, Thawra.

122 Ma'arrī, Risäla. See the new complete translation by van Gelder/Schoeler, The epistle of forgiveness.
} 
Others have preferred to continue in the vein of Sufi spiritual and interiorized interpretations of hell. ${ }^{123} \mathrm{An}$ important contributor to this line of thought is the Pakistani reformer Muhammad Iqbal (d. 1938). Just as al-Zahāwī updates al-Ma'arrī with modern science, so Iqbal combines the eschatological thought of Ibn al-Arabī and Rūmī with the thought of 2oth-century Western philosophers such as Henri Bergson (d. 1941). Iqbal sees paradise and hell primarily as metaphors for the inner psychic and intellectual developments of the individual. In Iqbal's take, when the Quran announces that "the fire of God, kindled, ... rises over the hearts [of people]" (Q 104:6-7), this refers to none other than the painful realization of one's failure as a human being. Paradise and hell, in Iqbal's phrase, are "states, not localities."124

Muslim theologians seeking a closer alignment with traditional Islamic theology have tended to find Iqbal's proposals insufficiently grounded in the tradition. As Fazlur Rahman criticizes, "the structural elements of [Iqbal's] thought are too contemporary to be an adequate basis for an ongoing Islamic metaphysical endeavor."125 Rahman is more sympathetic to Muhammad 'Abduh's (Egypt, d. 1905) attempt to "resurrect ... rationalism", such as he finds it in the example of the Mu'tazilites of the early centuries of Islam. ${ }^{126}$ 'Abduh, in his seminal Risālat al-tawhìd ("Epistle of Unity"), judged that Muslims are not required to believe in the corporeal particulars of the afterlife, even if these are recorded in "clear" (zähir) traditions; a general affirmation of the doctrine of life after death, including postmortem rewards and punishment, was enough, in his view, to qualify someone a "true believer" (mu'min haqq). ${ }^{127}$ In 'Abduh's wake, also Ibn Qayyim al-Jawziyya's "universalist" notion of fanā' al-nār has found important advocates among Muslim intellectuals and theologians, including the likes of Rashīd Riḍā (Egypt, d. 1935), İzmirli Ismail Hakkı (Turkey, d. 1946), and Yūsuf al-Qarādāwī (Egypt/Qatar, b. 1926). ${ }^{128}$

In spite of these developments, modern and contemporary eschatologists in the Muslim world often follow the traditional path of collecting hadith, though this endeavor is frequently clothed in modern Arabic and engages, albeit superficially, issues of modernity. The late 'Umar Sulaymān al-Ashqar (d. 2012) can serve as an example of this trend. A prolific neo-Salafi writer and long-time

\footnotetext{
123 Smith/Haddad, Islamic understanding 127-46.

124 Iqbal, Reconstruction 98.

125 Rahman, Islam and modernity 132.

126 Ibid., 153 .

127 'Abdūh, Risālat al-tawhīd 178.

128 On Rị̣ā and al-Qaraḍāwī, see Ryad, Eschatology (forthcoming). On Hakkl, see Kaya, İzmirli Ismail Hakkı.
} 
professor of Islamic law at various universities in Kuwait and Jordan, al-Ashqar is the author-compiler of a work in three volumes entitled al-Yawm al-äkhir ("Endtime"), the last volume of which deals with paradise and hell. Strikingly, though he looks up to Ibn al-Qayyim as a forefather of Salafism, al-Ashqar rejects the doctrine of $\operatorname{fan} \bar{a}^{3}$ al-nār. ${ }^{129}$ In his discussion of the hadith that "most of the inhabitants of hell are women", al-Ashqar first quotes a long passage from al-Qurțubī, in which he rehearses the stock repertoire of arguments why women are less likely to enter paradise: they suffer from a deficiency in intellectual ability (nuqșān al-uqül), are too attached to the ephemeral world of the here-and-now, subject to uncontrollable passions, etc. Al-Ashqar then adds that "in spite of this, many women are good and pious (șälihăt) ... and a great number of them enter paradise, including those who are superior to many a man in terms of the soundness of their belief and their pious actions." ${ }^{\prime 30}$ Such statements only thinly veil the chauvinism that is typical of neo-Salafism. Contemporary traditionist works like al-Yawm al-äkhir, therefore, do not represent a great advance over the medieval manuals, except perhaps in the sense that they are presented in such a way as to make traditional teachings more easily digestible for a broad audience. At the same time, medieval works like the Daqāiq al-akhbār or the Tadhkira of al-Qurțubī are reissued frequently in Arabic lands and beyond, and are widely on sale in bookshops and street corners all over the Islamic world.

In conclusion, this introduction has put into relief the many aspects that make the investigation of the Islamic hell a worthwhile scholarly endeavor. There is no shortage of monographs written about the history of the afterlife in the West. ${ }^{131}$ Also hell has been subject of numerous studies, ${ }^{132}$ not to mention

129 Ashqar, Yawm 44-6. On attempts by contemporary Muslim theologians to argue that Ibn Taymiyya and Ibn al-Qayyim actually affirmed the eternity of hell, see Hoover, Against Islamic Universalism.

130 Ashqar, Yawm 83-4.

131 See, for instance, the recent studies of Casey, After lives; Segal, Life after death. Both Casey and Segal include chapters on Islam in their surveys; both, however, rely exclusively on the secondary literature on Islamic eschatology. Casey attests Islamic eschatology an "extraordinary ... capacity to find arresting visual images for scarcely graspable ideas." See Casey, After lives 144. Segal suggests that "Islamic views of the afterlife are just as rich and manifold as in Judaism or Christianity, but ... different in some important ways;" he identifies the study of "the whole tradition" as a desideratum. See Segal, Life after death 639 .

132 In lieu of the many, reference can be made to Minois, Histoire de l'enfer; Turner, History of hell. 
the spate of biographies of Satan in the Christian tradition. ${ }^{133}$ As noted at the beginning of this introduction, very few comparable works exist in scholarship on Islam. It is hoped that this volume can be a first step toward filling this lacuna.

\section{Bibliography}

\section{$1 \quad$ Sources}

'Abd al-Razzāq al-Ṣan‘ānī: Al-Muṣannaf fì l-ḥadīth, ed. Ḥabīb al-Raḥmān al-A'ẓamī, 11 vols, Beirut 1970-2.

'Abduh, Muhammad: Risālat al-tawhīd, Beirut 1414/1994.

Abū Nu'aym: Hilyat al-awliyä', Beirut ${ }^{4}{ }^{1405} / 1984-5$.

al-Ash'arī: Maqālāt al-islāmiyȳ̄n, ed. Ritter, H., Wiesbaden ${ }^{2} 1963$.

al-Ashqar, 'Umar Sulaymān: Al-Yawm al-akhìr, al-juz' al-thālith: al-janna wa-l-nār. Amman 1991.

Ațfayyish, Muḥammad b. Yūsuf: Al-junna fi wașf al-janna. Muscat 1405/1985.

al-Bahrānī, Hāshim b. Sulaymān: Ma'ālim al-zulfā fı̀ma'ārif al-nash'a al-ūlā wa-l-ukhrā,

Qum 1430/[2009].

Daqāंiq al-akhbār, Beirut 1984.

al-Dhahabī: Al-Kabā’ir, ed. Bashīr Muhạmmad 'Uyūn, Riyadh 1423/2002.

al-Durar al-hisān fì l-ba'thwa-naīm al-jinān, ed. Muhammad Z.M. 'Azb, Cairo 1414/1993. al-Fākihī: Akhbār Makka fı̀ qadīm al-dahr wa-hadìthihi, ed. 'Abd al-Malik b. 'Abdallāh b.

Duhaysh, 6 vols in 3, Beirut ${ }^{2} 1414 / 1994$.

al-Ghazālī: Al-Durra l-fākhira, ed. Gautier, L. Geneva 1877, tr. Smith, J.I.: The precious pearl, Missoula 1979.

— I Ihyä' 'ulüm al-dìn, 5 vols, [Cairo n.d.], partial tr. Winter, T.: The remembrance of death and the afterlife: Book XL of The revival of the religious sciences, Cambridge 1989 .

—- Nașihhat al-mulk, ed. Jalāl al-Dīn Humā'ī, Tehran 1982.

Hujwīin: Kashf al-mahjūb, ed. Zukovskij, V.A., Leningrad 1926, tr. Nicholson, R.A.: The "Kashf al-Mahjūb," the oldest Persian treatise on Sufism, London 1911, repr. London 1959, 1976.

Ibn Abī l-Dunyā: Șifat al-nār, ed. Muḥammad Khayr Ramaḍān Yūsuf, Beirut 1427/1997. Ibn Abī Shayba: K. al-Muṣannaf, ed. Ḥamad b. 'Abdallāh al-Jum‘a and Muhammad b.

Ibrāhīm al-Luḥaydān (Lahīdān?), 16 vols, Riyadh 1425/2004.

Ibn Hanbal: Musnad, 6 vols, Cairo 1313/1895.

133 The standard biography is that by Kelly, Satan. The devil in Islam has been the object of a number of studies, see notably Awn, Satan's tragedy; Bowman, The poetics of Ibliss. 
- K. al-Zuhd, Mecca 1357/[1938-9], repr. Beirut 1396/1976.

Ibn Ḥajar al-Haythamī: Al-Zawājir 'an iqtirāf al-kabā’ir, Beirut 1998.

Ibn Rajab: Al-Takhwīf min al-nār, Beirut 1982.

Iqbāl, M.: The reconstruction of religious thought in Islam, ed. Sheikh, M.S., Lahore 1986. al-Ma'arrī: Risālat al-ghufrān, ed. Bint al-Shāți', Cairo [195-], tr. van Gelder, G. and

Schoeler, G.: The epistle of forgiveness, New York 2013.

al-Majlisī: Bihāar al-anwār, 110 vols in 66, Beirut 1429/2008.

al-Makkī, Abū Țālib: Qūt al-qulūb, tr. Gramlich, R.: Die Nahrung der Herzen, Stuttgart 1992-5.

al-Muttaqī al-Hindī: Kanz al-'ummāl, ed. Mahmūd 'Umar al-Dimyāṭī, 16 vols in 8, Beirut $1419 / 1998$.

Nasafī, 'Azīz-i: Al-Insān al-kāmil, ed. Molé, M.: Le livre de l'homme parfait, Tehran 1962. al-Pazdawī: Ușūl al-dīn, ed. Linss, H.P., Cairo 1963.

al-Qārī al-Harawī: Al-Qawl al-sadìd fì khulf al-wa'ìd, Țanțā 1412/1992.

Qurrat al-'uyūn wa-mufrị̣ al-qalb al-maḥzūn, printed on the margin of al-Sha'rānī: Mukhtașar Tadhkirat al-Qurțub̄, Cairo 1358/1939.

al-Qurțubī: Al-Tadhkira fi aḥwāl al-mawtā wa-umūr al-ākhira, ed. Aḥmad Hijāāī al-Saqqā, 2 vols in 1, Cairo 1980.

al-Qushayrī: Kitāb al-Mi'rāj, ed. 'Alī Ḥasan 'Abd al-Qādir, Cairo 1384/1964.

Rahman, F.: Islam and modernity: Transformation of an intellectual tradition, Chicago 1982.

al-Rāzī, Fakhr al-Dīn: Al-Tafsìr al-kabìr [= Mafātīh al-ghayb], 32 vols, Cairo [1934-62].

Rūmī, Jalāl al-Dīn: Mathnawì, ed., tr. and comment. Nicholson, R.A.: The Mathnawí of Jalálu'ddín Rúmí, 8 vols, London 1925-40.

al-Saffārīnī: Al-Buḥūr al-zākhira fì 'ulūm al-ākhira, ed. 'Abd al-'Azīz Aḥmad al-Mushayqih, Riyadh 2009.

Saīì b. Janāḥ: Sifat al-janna wa-l-nār, in al-Shaykh al-Mufìd: K. al-Ikhtiṣāṣ, ed. 'A.A. al-Ghaffārī, Tehran 1379, 345-65.

al-Samarqandī: Tafsìr, ed. Maḥmūd al-Mațrajī, Beirut n.d.

Ṣiddīq Ḥasan Khān: Yaqzat ùlì l-i'tibār mimmā warada fì dhikr al-nār wa-aṣhāb al-nār.

Beirut 1426/2005, abridged version:Jahannam: ahwāluhā wa-ahluhā. Amman 1408 [1987-8].

al-Sijistānī: Kashf al-mahjūb, tr. Corbin, H.: Le dévoilement des choses cachées, Lagrasse 1988.

: Al-Risāla al-bāhira, ed. B. Hīrjī, B., in Tahqüqāt-i islāmī, 7 (1371 sh./1992), 37-50. al-Suyūṭì:Al-Budūr al-sāfira fì 'ulūm al-ākhira, ed. Abū 'Abdallāh Muḥammad al-Shāfī̄, Beirut 1416/1996.

: al-La'ālì al-mașnū'a, ed. Abū 'Abd al-Raḥmān Ṣalaḥ b. Muḥammad Ibn 'Uwayḍa, 3 vols, Beirut 1417/1996.

: Sharḥ al-ṣudūr, Damascus-Beirut ${ }^{5}$ 1429/2008. 
al-Ṭabarī:Jāmic al-bayān, ed. Muḥammad Shākir and Aḥmad Shākir, Cairo 1374-/1954-. al-Tha'labī: Qișaṣ al-anbiyā', Cairo [1960]. : Tafsìr, ed. 'Alī 'Āshūr, 10 vols, Beirut 1422/2002.

Ṭūsī, Muḥammad b. Maḥmūd: 'Ajāyib al-makhlūqāt, ed. Manūchihr Sutūdah, Tehran [1345sh./1966].

Ṭūsī, Nașīr al-Dīn: Al-Mabda'wa-l-macād [= Aghāz-u anjām ], tr. Badakhchani, S.J.: Shi ${ }^{i} i$ interpretations of Islam: Three treatises on Islamic theology and eschatology, London 2010, 45-88.

al-Wahrānī: Al-Manām al-a'̧am, in Ibrāhīm Sha'lān and Muḥammad Naghsh (eds): Manāmāt al-Wahrānī wa-maqāmātuhu wa-rasā̇iluhu, Cairo 1387/1968, 17-6o.

al-Wāsiṭi: Faḍ̂̉il al-Bayt al-Muqaddas, ed. Isaac Hasson, I., Jerusalem 1979.

Wensinck, A.J.: Concordance et indices de la tradition musulmane, 8 vols, Leiden 1936-88.

Yāqūt: Mu'jam al-buldān, Beirut 1955-7.

al-Zahāwī, Jamīl Șidqī: Thawra fì al-jahīm, in ad-Duhūr, 1,6 (1931), 641-69.

\section{$2 \quad$ Studies}

Abrahamov, B.: The creation and duration of paradise and hell in Islamic theology, in Der Islam, 79,1 (2002), 87-102.

Abu-Deeb, K.: The imagination unbound: Al-adab al-'ajā'ibī and the literature of the fantastic, London 2007.

Awn, P.: Satan's tragedy and redemption: Iblīs in Sufi psychology, Leiden 1983.

al-Azmeh, A.: Rhetoric for the senses: A consideration of Muslim paradise narratives, in Journal of Arabic Literature, 26 (1995), 215-31.

Andrae, T.: Der Ursprung des Islams und das Christentum. Uppsala-Stockholm 1926.

Asín Palacios, M.: La escatología musulmana en la Divina Comedia, Madrid 1919, ${ }^{4} 1984$.

Bauer, Th.: Islamische Totenbücher, in Leder, S., Kilpatrick, H., Martel-Thoumian, B. and Schönig, H. (eds): Studies in Arabic and Islam: Proceedings of the 19th Congress, Union Européenne des Arabisants et Islamisants, Halle 1998, Leuven 2002, 421-36.

Bodman, W.: The poetics of Iblīs: Narrative theology in the Qur'ān, Cambridge MA 2011.

Canova, G.: Animals in Islamic paradise and hell, in Dévényi, K. and Fodor, A. (eds): Proceedings of the colloquium on Paradise and Hell in Islam, Keszthely, 7-14July 2002, in The Arabist, 28-29 (2008), 55-81.

Carra de Vaux: Fragments d'eschatologie musulmane. In Compte rendu du troisième congrès scientifique international des catholiques tenu à Bruxelles du 3 au 8 septembre 1894, II, Bruxelles 1895, 5-34.

Casey, J.: After lives: A guide to heaven, hell, and purgatory, Oxford 2009.

Daniel, N.: Islam and the West: The making of an image, Edinburgh 196o, rev. ed. Oxford 1993 . 
Dévényi, K. and Fodor, A. (eds): Proceedings of the colloquium on Paradise and Hell in Islam, Keszthely, 7-14July 2002, in The Arabist, 28-29 (2008), 1-195; 30 (2012), 1-98.

El-Saleh, S.: La vie future selon le Coran, Paris 1971.

Gardet, L.: Dieu et la destinée de l'homme, Paris 1967.

: Djanna, in $E I^{2}$, II, 447a-452a.

: Djahannam, in $E I^{2}$, II, 381b-382a.

Goldziher, I.: Die Richtungen der koranischen Koranauslegung, Leiden 1920.

Gwynne, R.W.: Hell and hellfire, in EQ, II, 414a-420a.

Hamza, F.: To hell and back: A study of the concepts of hell and intercession in early Islam, $\mathrm{PhD}$ Oxford 2002.

Heinen, A.: Islamic cosmology: A study of al-Ṣuyūțis al-Hay’a al-sanīya fì l-hay’a al-sunnīya, Beirut 1982 .

Himmelfarb, M.: Tours of Hell: An apocalyptic form in Jewish and Christian literature, Philadelphia 1983 .

Hoover, J.: Against Islamic Universalism? ‘Alī al-Harbī’s 1990 Attempt to Prove That Ibn Taymiyya and Ibn Qayyim al-Jawziyya Affirm the Eternity of Hell-Fire, in Krawietz, B. und Tamer, G. (eds): Islamic theology, philosophy and law: Debating Ibn Taymiyya and Ibn Qayyim al-Jawziyya, Berlin 2013, 377-99.

— Islamic universalism: Ibn Qayyim al-Jawziyya's Salafì deliberations on the duration of Hell-fire, in $M W, 99$ (2009), 181-201.

Horovitz, J.: Das koranische Paradies, in Scripta Universitatis atque Bibliothecae Hierosolymitanarum (Jerusalem, 1923), repr. in Paret, R. (ed.): Der Koran, Darmstadt 1975, $53^{-75}$.

Jenkinson, E.J.: The rivers of paradise, in $M W, 19$ (1925), 151-5.

Jeschke, J.: Ğahannam und al-nār-das Gegenparadies im Koran, in Tubach, J., DrostAbgarjan, A. and Vashalomidze, S.G. (eds): Sehnsucht nach der Hölle? Höllen- und Unterweltsvorstellungen in Orient und Okzident, Wiesbaden 2012, 1-17.

Jones, A.: Heaven and hell in the Qurān, in Dévényi, K. and Fodor, A. (eds): Proceedings of the colloquium on Paradise and Hell in Islam, Keszthely, 7-14 July 2002, in The Arabist, 28-29 (2008), 105-22.

Kaya, V.: İzmirli Ismail Hakkı cehennemin sonluluğu hakkında risalesi, in Uludağ Üniversitesi İlâhiyat Fakültesi Dergisi, 18,1 (2009), 529-57.

Kelly, H.: Satan: A biography, Cambridge-New York 2006.

Kermani, N.: Gott ist schön. Das ästhetische Erleben des Koran, Munich 42011.

: Der Schrecken Gottes. Attar, Hiob und die metaphysische Revolte, Munich 2005.

Khalil, M.H.: Islam and the fate of others: The salvation question, Oxford 2012.

Kinberg, L.: Paradise, in EQ, IV, 12a-20a.

Lange, Ch.: Hell ( jahannam, nār, zabāniya, zaqqūm), in $E I^{3}$, s.v.

— : Islamische Höllenvorstellungen: Genese-Struktur-Funktion, in Hornung, E. and Schweizer, A. (eds): Eranos Jahrbuch:Jenseitsreisen, Basel 2011, 153-193. 
- Justice, punishment, and the medieval Muslim imagination, Cambridge 2008.

—- "On That Day When Faces Will Be Black" (Q3:106): Toward a Semiology of the Human Face in the Arabo-Islamic Tradition, in JAOS, 127, 4 (2007), 429-46.

—- Paradise and hell in Islamic traditions, Cambridge 2015.

: Paradise in the Islamic religious imagination, in Scafi, A. (ed.): The cosmography of paradise, London (forthcoming).

- Sins, expiation, and non-rationality, in Reinhart, K. and Gleave, R. (eds): Islamic law in theory: Studies on jurisprudence in honor of Bernard Weiss, Leiden 2014, 143-75.

- : The discovery of paradise in Islam (Inaugural Lecture, Utrecht University, 16 April), Utrecht 2012, open access: http://igitur-archive.library.uu.nl/th/2012-0713200425/UUindex.html.

: Where on earth is hell? State Punishment and Eschatology in the Islamic Middle Period, in Lange, Ch. and Fierro, F. (eds): Public violence in Islamic societies: Power, discipline and the construction of the public sphere, 7 th-19th centuries, Edinburgh 2009, 156-78.

Lohlker, R. and Nowak, A.: Das islamische Paradies als Zeichen: Zwischen Märtyrerkult und Garten, in WZKM, 99 (2009), 199-225.

MacDonald, J.: Islamic Eschatology I-VI, in Islamic Studies, 3 (1964) 285-308, 485-519; 4 (1965) 55-102, 137-79; 5 (1966) 129-197, 331-383.

Madigan, D.: Themes and topics, in McAuliffe, J.D. (ed.): The Cambridge companion to the Qur'ān, Cambridge 2006, 80-95.

Malti-Douglas, F.: Faces of sin: Corporal geographies in contemporary Islamist discourse, in Law, J.M. (ed.): Religious reflections on the human body, Bloomington 1995, $67-75$.

Meier, F.: Abū Saìd-i Abūl-Khayr (357-440/1067-1049). Wirklichkeit und Legende, Leiden 1976.

: The ultimate origin and the hereafter in Islam, in Tikku, G.L. (ed.): Islam and its cultural divergence: Studies in honor of Gustav E. von Grunebaum, Urbana [1971], 96-112.

Melchert, Ch.: Exaggerated fear in the early Islamic renunciant tradition, in JRAS, series 3, 21,3 (2011), 283-300.

Meyer, J: Die Hölle im Islam, PhD Basel 1901.

Minois, G.: Histoire de l'enfer, Paris 1994.

Monfarrer Sala, J.P.: A propósito de Wādī Yahannam, in Al-Andalus Maghreb, 5 (1997), 149-62.

Murata, S., and Chittick, W.C.: The vision of Islam, New York 1997.

Neuwirth, A.: Der Koran als Text der Spätantike. Ein europäischer Zugang, Berlin 2010.

$\longrightarrow$ : Form and Structure of the Qurāan, EQ, II, 245b-266a. 
: Reclaiming paradise lost: The Qur'an in conversation with Jewish, Christian and pagan traditions, in Bruns, P. and Luthe, H.O. (eds): Orientalia Christiana. Festschrift für Hubert Kaufhold zum 70. Geburtstag, Wiesbaden 2013, 333-54.

Orsi, R.: Jesus held him so close in his love for him that he left the marks of his passion on his body, in Between heaven and earth: The religious worlds people make and the scholars who study them, Princeton 2005, 1-18.

O'Shaughnessy, Th.: Eschatological themes in the Qur'ān, Manila 1986.

: The seven names for Hell in the Qurān, in BSOAS, 24 (1961), 444-69.

Pagani, S.: Vane speranze, false minacce. L'islam e la durata dell'inferno, in Migliore, M. Ch. and Pagani, S. (eds): Inferni temporanei. Visioni dell'aldilà dall'estremo Oriente all'estremo Occidente, Rome 2011, 179-222.

Radscheit, M.: Der Höllenbaum, in Nagel, T. and Müller-Luckner, H. (eds): Der Koran und sein religiöses und kulturelles Umfeld, Munich 2010, 97-134.

Raven, W.: A Kitāb al-'Azama: on cosmology, hell and paradise, in de Jong, F. (ed.): Miscellanea Arabica et Islamica. Dissertationes in Academia Ultratrajectina prolatae, Leuven 1993, 135-142.

Reinhart, K.: The here and the hereafter in Islamic religious thought, in Bloom, Sh. and Bloom, J.M. (eds): Images of paradise in Islamic art, Hanover $\mathrm{NH}$ 1991, 15-24.

Rentz, G.: Barhūt, in $E I^{2}$, I, 1045a.

Ritter, H.: Die Aussprüche des Bāyezīd Bisțāmī. Eine vorläufige Skizze, in Meier, F. (ed.): Westöstliche Abhandelungen. Rudolf Tschudi zum siebzigsten Geburtstag überreicht von Freunden und Schülern, Wiesbaden 1954, 231-43.

Rosenthal, F.: Reflections on love in paradise, in Marks, J.H. and Good, R.M. (eds): Love and death in the ancient Near East, Guilford CT 1987, 247-54.

—-: "Sweeter than hope": Complaint and hope in medieval Islam, Leiden 1983.

Rustomji, N.: The Garden and the Fire: Heaven and hell in Islamic culture. New York: Columbia University Press, 2009.

Ryad, U.: Eschatology between reason and revelation, in Günther, S. and Lawson, T. (eds): Roads to paradise, Leiden (forthcoming).

Schimmel, A.: The celestial garden in Islam, in E.B. MacDougall, E.B. and Ettinghausen, R. (eds): The Islamic garden, Washington D.C. 1976, 11-39.

Segal, A.: Life after death: A history of the afterlife in the religions of the West, New York 2004.

Séguy, M.-R.: The miraculous journey of Mahomet, New York 1977.

Sells, M.: Approaching the Qur'ān: The early revelations, Ashland oR 1999.

Smith, J.I. and Haddad, Y.Y.: The Islamic understanding of death and resurrection, Albany 1981, repr. Oxford-New York 2002.

Sviri, S.: Between fear and hope: On the coincidence of opposites in Islamic mysticism, in JSAI, 9 (1987), 316-49. 
Szombathy, Z.: Come Hell or high water: Afterlife as a poetic convention in mediaeval Arabic literature, in Dévényi, K. and Fodor, A. (eds): Proceedings of the colloquium on Paradise and Hell in Islam, Keszthely, 7-14 July 2002, in The Arabist, 28-29 (2008), 163-78.

Thomassen, E.: Islamic hell, in Numen, 56 (2009), 401-16.

Tottoli, R.: Muslim eschatological literature and Western Studies, in Der Islam, 83 (2008), 452-77.

— The Qur’an, Qur'anic exegesis and Muslim traditions: The case of zamharir (Q. 76:13)", in JQS, 10, 1 (2009), 142-52.

: Tours of Hell and punishments of sinners in Mi'rāj narratives: Use and meaning of eschatology in Muhammad's Ascension, in Gruber, Ch. and Colby, F. (eds): The Prophet's Ascension: Cross-cultural encounters with the Islamic Mirāj tales, Bloomington 2010, 11-26.

:The story of Jesus and the skull in Arabic literature: The emergence and growth of a religious tradition, in JSAI, 28 (2003), 225-58.

: What will be the fate of the sinners in Hell? The categories of the damned in some Muslim popular literature, in Dévényi, K. and Fodor, A. (eds): Proceedings of the colloquium on Paradise and Hell in Islam, Keszthely, 7-14July 2002, in The Arabist, 28-29 (2008), 179-95.

Tubach, J.: Die Schönheiten des koranischen Paradieses: Huris, Weintrauben und Männerphantasien, in Tubach, J., Drost-Abgarjan and Vashalomidze, S. (eds): Sehnsucht nach dem Paradies. Paradiesvorstellungen in Judentum, Christentum, Manichäismus und Islam, Wiesbaden 2010, 179-99.

Turner, A.: The history of hell, New York 1991.

van Ess, J.: The flowering of Muslim theology. Cambridge MA 2006.

von Grunebaum, G.: Ausbreitungs - und Anpassungsfähigkeit, in idem: Studien zum Kulturbild und Selbstverständnis des Islam, Zurich-Stuttgart 1969, 11-22.

Vuckovic, B.: Heavenly journeys, earthly concerns: The legacy of the mi'rāj in the formation of Islam, New York 2005.

Watt, W.M. (tr.): Islamic creeds: A selection, Edinburgh 1994.

Wendell, Ch.: The denizens of paradise, Humaniora Islamica, 2 (1974), 29-59. 